\title{
Pengaruh Pemberian Probiotik Bacillus sp. terhadap Profil Kualitas Air, Pertumbuhan dan Kelangsungan Hidup Benih Ikan Lele (Clarias gariepinus)
}

se of Bacillus sp. as Probiotic Effect on Water Quality, Growth, and Survival Rate Catfish Seeds (Clarias gariepinus)

\author{
Oleh \\ Yuke Eliyani $^{\bowtie}$, Hendria Suhrawardan, Sujono \\ Sekolah Tinggi Perikanan, Jurusan Penyuluhan Perikanan \\ Jalan Cikaret Nomor 1 Bogor 16001, Jawa Barat
}

Diterima: 10 Maret 2015; Disetujui: 13 Juni 2015

\begin{abstract}
Abstrak
Dalam pengembangan budidaya perikanan, probiotik dinilai memiliki peranan penting untuk meningkatkan efektifitas kegiatan tersebut. Penelitian ini bertujuan untuk mengetahui pengaruh pemberian probiotik Bacillus sp terhadap profil kualitas air, kelangsungan hidup dan pertumbuhan benih ikan lele (Clarias gariepinus), dengan melakukan pemeliharaan ikan pada beberapa perlakuan, yaitu kontrol, penambahan bakteri dengan dosis. $10 \mathrm{ml} / \mathrm{m}^{3}$ serta $20 \mathrm{ml} / \mathrm{m}^{3}$ Nilai DO dari media kontrol Perlakuan I dan Perlakuan II secara berturut-turut adalah 6,80 ppm; 6,89 ppm dan 6,92 ppm. Nilai suhu mulai dari kontrol sampai perlakuan I dan II adalah $28^{\circ} \mathrm{C}$. Nilai pH untuk kontrol perlakuan I dan II adalah 6,6; 6,4 dan 6,6. Berdasarkan uji lanjut $(\mathrm{p}<0.05)$ dapat dilihat bahwa perlakuan I (pemberian probiotik $10 \mathrm{ml} / \mathrm{m}^{3}$ ) memiliki nilai pertumbuhan harian tertinggi sebesar 12,52 $\pm 0,29 \mathrm{~b}$, disusul perlakuan II (pemberian probiotik $20 \mathrm{ml} / \mathrm{m}^{3}$ ) sebesar 12,42 $\pm 0,33 \mathrm{~b}$, serta kontrol sebesar 10,72 $\pm 0,09 \mathrm{a}$. Perlakuan penambahan bakteri probiotik memberikan hasil yang terbaik untuk pertumbuhan berat pada dosis $10 \mathrm{ml} / \mathrm{m}^{3}$ dengan nilai 12,52 $\pm 0,29$ dibanding dengan kontrol dan perlakuan yang lain. Tingkat kelangsungan hidup ikan uji selama masa pemeliharaan berkisar antara 79,8 $-87,5 \%$.
\end{abstract}

Kata kunci : benih lele, pertumbuhan, probiotik, Bacillus sp, Nitrogen

\begin{abstract}
In development of fisheries, probiotics are considered to have an important role to improve the effectiveness of these activities. This study aims to determine the effect of probiotic Bacillus sp on the profile of water quality, viability and growth of the seed catfish (Clarias gariepinus), to perform maintenance on some of the fish treatment, the control, the addition of a dose of bacteria. $10 \mathrm{ml} / \mathrm{m} 3$ and $20 \mathrm{ml} / \mathrm{m} 3$ Value of media control DO Treatment I and Treatment II respectively are $6.80 \mathrm{ppm} ; 6.89 \mathrm{ppm}$ and $6.92 \mathrm{ppm}$. Value temperatures ranging from control to treatment I and II is $280 \mathrm{C}$. The $\mathrm{pH}$ value for the control treatment I and II was 6.6; 6.4 and 6.6. Based on advanced test (p $<0.05)$, it can be seen that the treatment I (probiotics $10 \mathrm{ml} / \mathrm{m} 3$ ) has the highest daily growth rate of $12.52 \pm 0,29 \mathrm{~b}$, followed by treatment of II (probiotics $20 \mathrm{ml} / \mathrm{m} 3$ ) of $12.42 \pm 0,33 \mathrm{~b}$, as well as control by $10.72 \pm 0,09 \mathrm{a}$. Treatment addition of probiotic bacteria provide the best results for weight growth at a dose of $10 \mathrm{ml} / \mathrm{m} 3$ with a value of $12.52 \pm$ 0,29dibanding with control and other treatments. The survival rate test fish during the maintenance period ranged between $79.8-87.5 \%$.
\end{abstract}

Keywords: catfish seed, growth, probiotic, Bacillus sp, Nitrogen

\section{Pendahuluan}

Latar Belakang

Keberhasilan suatu kegiatan budidaya

ikan sangat ditentukan oleh berbagai faktor diantaranya adalah kualitas air yang meliputi berbagai parameter yakni fisika, kimia maupun biologi. Kualitas air yang tidak memenuhi

$\triangle$ Penulis korespondensi

Alamat surel:yukeeliyani@yahoo.com persyaratan untuk mendukung pertumbuhan ikan seringkali disebabkan oleh berbagai faktor seperti akumulasi bahan organik di dasar kolam yang berasal dari feses ikan, sisa pakan, penggunaan pupuk organik yang berlebihan maupun bahan lainnya. Kondisi ini dapat ditemukan pada budidaya dengan padat tebar tinggi sehingga input produksi yang dibutuhkan akan semakin meningkat pula, contohnya pada kegiatan pembesaran lele baik di ruang tertutup 
Pengaruh Pemberian Probiotik Bacillus sp. terhadap Profil Kualitas Air,

Pertumbuhan dan Kelangsungan Hidup Benih Ikan Lele (Clarias gariepinus)

seperti dalam bak, maupun di luar ruangan seperti pada kolam tanah ataupun terpal.

Penurunan nilai kualitas air dalam media budidaya tentu akan berpengaruh pada tingkat produksi, sehingga berbagai upaya telah dicoba diantaranya dengan memanfaatkan mikroorganisma yang menguntungkan atau yang lebih dikenal dengan istilah probiotik. Probiotik dapat diaplikasikan untuk memperbaiki kondisi kualitas air dengan bertindak sebagai agen pengurai berbagai unsur seperti $\mathrm{NH}_{3}, \mathrm{NO}_{3}, \mathrm{NO}_{2}$, maupun bahan organik lainnya, dan mampu menekan pertumbuhan populasi alga biru. Beberapa jenis mikroorganisma sebagai probiotik pengurai antara lain Bacillus sp dan Pseudomonas fluorescense (Balcazar et al, 2006). Abareethan et al (2015), Lazado dan Caipang (2014) menyatakan bahwa Bacillus spp. Memberikan kontribusi sebagai agen probiotik dalam bidang perikanan budidaya.

Efektivitas probiotik sangat tergantung pada jenis mikroorganisma yang digunakan karena populasi mikroorganisma yang hidup pada suatu lingkungan dengan kondisi fisika kimia berbeda kemungkinan akan berbeda pula. Akan lebih efektif apabila probiotik menggunakan jenis mikro organisme indigenous (asli) yaitu yang diperoleh berasal dari lingkungan yang sama dengan ikan yang dibudiayakan. Mikroorganisme tersebut dipastikan akan lebih mampu beradaptasi dengan lokasi perlakuan dibandingkan jika mikro organisma diperoleh dari lingkungan yang berbeda.

Pemanfaatan probiotik dalam menekan atau mendegradasi unsur-unsur yang berpengaruh terhadap kualitas air media budidaya diharapkan tidak menimbulkan dampak negatif terhadap sistem keseimbangan ekologis mikrobia, ramah lingkungan, serta tidak meninggalkan residu (food security dan food safety). Pengendalian hayati dalam akuakultur dengan menggunakan probiotik merupakan salah satu cara yang perlu dikembangkan untuk menciptakan sistem akuakultur yang ramah lingkungan. H, Jamali et al (2014), Zoekaifar et al (20114) menyatakan bahwa probiotik Bacillus memberikan kontribusi poisitif dalam lingkungan media budidaya. Pengendalian hayati ini dapat diterapkan pada berbagai tahapan akuakultur dan pada berbagai komoditas perikanan. Beberapa pengamalam lapangan memperlihatkan, pembesaran ikan lele dengan menggunakan probiotik dapat mengurangi pasokan pakan; sehingga lebih ekonomis. Tercatat FCR untuk pembesaran lele sekitar 0,8-1,0

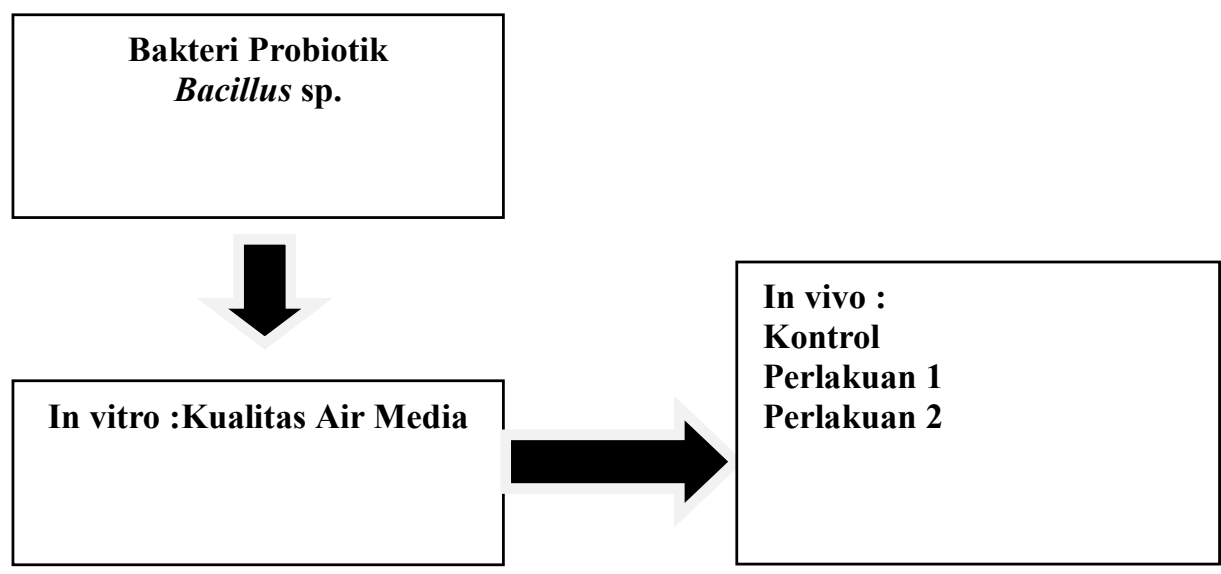

Kerangka Permasalahan 
Tujuan

Penelitian ini bertujuan untuk mengetahui pengaruh pemberian probiotik Bacillus $\mathrm{sp}$ terhadap profil kualitas air, kelangsungan hidup dan pertumbuhan benih ikan lele (Clarias gariepinus).

\section{Manfaat Penelitian}

Pemberian bakteri probiotik Bacillus sp. diharapkan dapat digunakan pada media pemeliharaan benih ikan lele (Clarias gariepinus), serta diharapkan juga dapat diperoleh informasi metoda pengaplikasiannya di lapangan.

\section{Bahan dan Metoda}

Waktu dan Tempat

Penelitian ini dilaksanakan mulai bulan September sampai dengan Oktober 2015 di Hatchery STP Jurusan Penyuluhan Perikanan, Laboratorium Analisis dan Kalibrasi Balai Besar Industri Agro.

Alat dan Bahan

Hewan Uji

Hewan uji yang digunakan adalah benih lele ukuran $4 \pm 0,3 \mathrm{~cm} /$ ekor yang diperoleh dari pembudidaya di Parung Kabupaten Bogor. Sebelum diberikan perlakuan, hewan uji diadaptasikan terlebih dahulu dalam wadah uji.

Bakteri Nitrifikasi/ Bakteri yang digunakan merupakan produk komersial yang memiliki kandungan bakteri Bacillus sp. Sumber Karbon Sumber karbon yang digunakan adalah molase dengan kandungan karbon sebesar 61,45\%.

Wadah dan Media Pemeliharaan

Wadah yang digunakan adalah bak semen berukuran $100 \times 150 \times 80 \mathrm{~cm}^{3}$ sebanyak 9 buah sebagai wadah pemeliharaan ikan. Pada masingmasing bak diisi air tawar sebanyak 400 liter dan benih ikan lele sebanyak 200 ekor/bak lengkap dengan sistem aerasinya.

\section{Peralatan}

Alat-alat yang digunakan meliputi peralatan aerasi, serokan ikan, penggaris, timbangan digital, tabung reaksi, cawan petri, pembakar bunsen, jarum ose, inkubator goyang (shaker), penangas air, inkubator (suhu ruang), autoklaf, oven, penangas air, mikropipet, heater, termometer, $\mathrm{pH}$ meter, DO meter, pipet, bulp, gelas piala, erlenmeyer, spektrofotometer, erlenmeyer, lemari es, vortex, alumunium foil, dan tissue.

\section{Metode Penelitian}

Persiapan Wadah

Sebelum digunakan bak dicuci dengan deterjen dan diisi air. Selanjutnya wadah berisi air tersebut disterilisasi menggunakan kaporit dengan dosis 10 ppm dan dibiarkan selama 4 hari, tanpa aerasi. Setelah itu air dibuang dan wadah diisi air tawar yang telah diendapkan sebanyak 400 liter dan diberi aerasi. Peralatan aerasi sebelum digunakan direndam terlebih dahulu dengan kaporit 10 ppm.

Pemeliharaan Ikan

Pemeliharaan ikan dilakukan selama 30 hari pada bak dengan volume air 400 liter. Jumlah ikan yang ditebar sebanyak 200 ekor/bak dengan bobot rata-rata $4 \pm 0,3$ gram dan panjang rata-rata $7 \mathrm{~cm}$. Pemberian pakan dilakukan sebanyak 2 kali sehari, yaitu pada pukul 07.00 dan 17.00 WIB. Jumlah pakan yang diberikan didasarkan pada dosis $3 \%$ dari biomass. Pemberian molase dilakukan satu kali dalam seminggu pada pukul 08,00 WIB. Sedangkan pemberian probiotik dilakukan setiap satu minggu sekali dengan konsentrasi masingmasing pada bak perlakuan 1 sebanyak $10 \mathrm{ml} / \mathrm{m}^{3}$ dan bak perlakuan 2 sebanyak $20 \mathrm{ml} / \mathrm{m}^{3}$. Parameter kualitas air dijaga agar tetap stabil pada kedua bak perlakuan tersebut. 
Pengaruh Pemberian Probiotik Bacillus sp. terhadap Profil Kualitas Air,

Pertumbuhan dan Kelangsungan Hidup Benih Ikan Lele (Clarias gariepinus)

Tabel 1. Data Kelimpahan Bakteri (koloni/ml)

\begin{tabular}{|c|c|c|}
\hline Perlakuan & Tebar & Panen \\
\hline Kontrol. & $2,0 \times 10^{3}$ & $1,9 \times 10^{4}$ \\
\hline $10 \mathrm{ml} / \mathrm{m}^{3}$ & $2,0 \times 10^{3}$ & $3,3 \times 10^{5}$ \\
\hline $20 \mathrm{ml} / \mathrm{m}^{3}$ & $2,0 \times 10^{3}$ & $1,9 \times 10^{5}$ \\
\hline
\end{tabular}

Perlakuan

Penelitian ini dilakukan dengan melakukan pemeliharaan ikan pada beberapa perlakuan, yaitu kontrol, penambahan bakteri dengan dosis. $10 \mathrm{ml} / \mathrm{m}^{3}$ serta $20 \mathrm{ml} / \mathrm{m}^{3}$.

Parameter Pengamatan

Selama masa pemeliharaan dilakukan sampling kualitas air, yang meliputi $\mathrm{pH}$, suhu, dissolved oxygen (DO), nitrit, nitrat,. Adapun total bakteri dihitung diawal dan akhir penelitian. Pengujian DO, suhu dan $\mathrm{pH}$ dilakukan di Laboratorium Kualitas Air STP Jurusan Penyuluhan Perikanan, sedangkan penghitungan nitrit, nitrat dan total bakteri dilakukan di Laboratorium Analisis dan Kalibrasi Balai Besar Industri Agro Bogor. Untuk parameter tingkat kelangsungan hidup (SR), pertumbuhan, dan efisiensi pakan dilakukan pada akhir pengamatan.

Tingkat Kelangsungan Hidup atau Survival Rate (SR)

Tingkat kelangsungan hidup (SR) ikan dihitung dengan menggunakan rumusEffendie (1979) :

$$
\mathrm{SR}=\frac{\mathrm{Nt}}{\mathrm{No}} \times 100 \%
$$

Keterangan :

$\mathrm{SR}=$ tingkat kelangsungan hidup (\%)

$\mathrm{Nt}=$ jumlah ikan pada waktu panen

No $=$ jumlah udang pada awal penebaran

Tingkat Pertumbuhan

Sampling pertumbuhan ikan uji dilakukan setiap dua minggu. Perhitungan pertumbuhan harian dilakukan menggunakan rumus berdasarkan Huismann (1987).

$$
\alpha=\left[\sqrt[t]{\left(\frac{W t}{W o}\right)}-1\right] \times 100 \%
$$

Keterangan :

$\alpha=$ laju pertumbuhan bobot harian (\%)

$\mathrm{Wt}=$ bobot rata - rata akhir $($ gr/ekor $)$

Wo= bobot rata - rata awal $($ gr/ekor $)$

$\mathrm{T} \quad=$ waktu (hari)

Pertumbuhan panjang

Sampling pertumbuhan ikan uji dilakukan

setiap dua minggu. Perhitungan pertumbuhan panjang dilakukan menggunakan rumus berdasarkan Effendie (1979):

$$
\begin{array}{ll}
\mathrm{P}=\mathrm{Lt}-\mathrm{Lo} & \\
\text { Keterangan: } & \\
\mathrm{P} \quad= & \text { pertumbuhan panjang }(\mathrm{cm}) \\
\mathrm{Lt} & \text { panjang rata-rata ikan di akhir } \\
& \text { pemeliharaan }(\mathrm{cm}) \\
\mathrm{Lo} & \text { panjang rata-rata ikan di awal } \\
& \text { pemeliharan }(\mathrm{cm})
\end{array}
$$

FCR

Pengukuran FCR dilakukan setelah selesai pemberian pakan perlakuan pada hari ke30. Perhitungan yang digunakan berdasarkan NRC (1993).

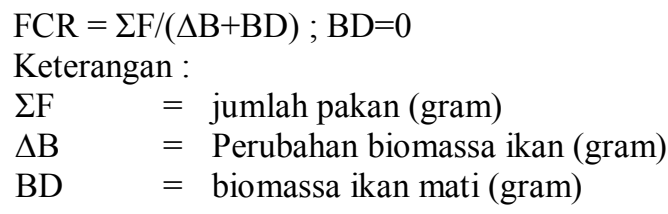

\section{Penghitungan Total Bakteri}

Total bakteri pada media pemeliharaan dihitung dengan menggunakan rumus :

$$
\begin{aligned}
& \text { Total Bakteri }=\sum \text { koloni } \mathrm{x} \underline{1} \underset{1}{1} \underline{1} \\
& \text { Fp ml sampel }
\end{aligned}
$$

Keterangan :

$\mathrm{Fp}=$ faktor pengenceran

Kualitas Air 
Tabel 2. Data Kualitas Air

\begin{tabular}{|c|c|c|c|c|c|c|c|c|c|c|}
\hline Perlakuan & \multicolumn{5}{|c|}{ Awal } & \multicolumn{5}{c|}{ Panen } \\
\cline { 2 - 12 } & DO & Nitrit & Nitrat & Suhu & pH & DO & Nitrit & Nitrat & Suhu & pH \\
\hline Kontrol. & 7,89 & 0,004 & 0,37 & 28 & 6,8 & 6,80 & 0,63 & 13,1 & 28 & 6,6 \\
\hline $10 \mathrm{ml} / \mathrm{m}^{2}$ & 7,89 & 0,004 & 0,37 & 28 & 6,8 & 6,89 & 0,02 & 0,22 & 28 & 6,4 \\
\hline $20 \mathrm{ml} / \mathrm{m}^{2}$ & 7,89 & 0,004 & 0,37 & 28 & 6,8 & 6,92 & 0,1 & 0,22 & 28 & 6,6 \\
\hline
\end{tabular}

$\mathrm{pH}$ dan Suhu

Pengukuran suhu dilakukan dengan

menggunakan termometer, sedangkan $\mathrm{pH}$ diukur

dengan menggunakan $\mathrm{pH}$ meter.

Nitrit $\left(\mathrm{NO}_{2}^{-}\right)$

Konsentrasi nitrit dihitung dengan rumus :

$\left(\mathrm{NO}_{2}\right) \mathrm{mg} / \mathrm{L}=\underline{\mathrm{As}} \times \mathrm{Cst}$ Ast

Keterangan :

Cst $=$ konsentrasi larutan standar (2 $\mathrm{mg} / \mathrm{L}$ )

Ast $=$ nilai absorbansi larutan standar

As $\quad=$ nilai absorbansi air sampel

\section{Nitrat $\left(\mathrm{NO}_{3}^{-}\right)$}

Konsentrasi nitrat dihitung dengan rumus :

$$
\left(\mathrm{NO}_{3}\right) \mathrm{mg} / \mathrm{L}=\underline{\text { As } \times \mathrm{Cst}}
$$$$
\text { Ast }
$$

Keterangan :

Cst $=$ konsentrasi larutan standar (2 $\mathrm{mg} / \mathrm{L}$ )

Ast $\quad=$ nilai absorbansi larutan standar

As $=$ nilai absorbansi air sampel

Prosedur Pengolahan Data
Penelitian ini menggunakan Rancangan Acak Lengkap (RAL) dengan satu faktor. Data dianalisis dengan sidik ragam (ANOVA) pada selang kepercayaan 95\%. Apabila terdapat perbedaan maka analisis data dilanjutkan dengan uji Duncan menggunakan program Xl-stat.

\section{Hasil dan Pembahasan}

Kelimpahan Bakteri dan Kualitas Air Penambahan bakteri probiotik dari jenis Bacillus sp. Pada penelitian ini, memberikan nilai kelimpahan bakteri (koloni/ml) yang berbeda pada kontrol, perlakuan 1 serta 2 . Hal ini dapat dilihat pada Tabel 1.

Dari tabel di atas, diketahui bahwa Jumlah total bakteri pada perlakuan I $\left(10 \mathrm{ml} / \mathrm{m}^{3}\right)$ dan II $\left(20 \mathrm{ml} / \mathrm{m}^{3}\right)$ lebih tinggi dibandingkan kontrol, dengan nilai $1,9 \times 10^{4}$ koloni $/ \mathrm{ml}, 3,3 \times 10^{5}$ koloni/ml, dan $1,9 \times 10^{5} \mathrm{ml} /$ koloni. Hal ini karena bakteri nitrifikasi yang ditambahkan ke dalam media uji Perlakuan I dan II mampu untuk

Tabel 3. Parameter Kualitas Air untuk Bakteri Nitrifikasi

\begin{tabular}{|c|c|}
\hline Parameter & Keterangan \\
\hline Dissolved oxygen (DO) & $\begin{array}{l}\text { Nitrifikasi mengkonsumsi oksigen dalam jumlah yang besar. Bakteri } \\
\text { nitrifikasi membutuhkan } 4.6 \mathrm{mg} \mathrm{O} 2 \text { untuk mengoksidasi } 1 \mathrm{mg} \text { amonia. } \\
\text { Untuk dapat bekerja bakteri nitrifikasi membutuhkan DO minimal } 2 \mathrm{mg} / 1\end{array}$ \\
\hline Kandungan BOD & $\begin{array}{l}\text { Bakteri nitrifikasi akan kalah berkompetisi dengan bakteri heterotrof dalam } \\
\text { perebutan DO dan nutrien. Oleh karenanya agar proses nitrifikasi dapat } \\
\text { mengambil alih, maka BOD terlarut harus dikurangi hingga nilainya turun } \\
\text { menjadi } 20-30 \mathrm{mg} / 1 \text { untuk mengurangi kompetisi tersebut. }\end{array}$ \\
\hline $\mathrm{pH}$ & $\begin{array}{l}\mathrm{pH} \text { ideal untuk bakteri nitrifikasi adalah } 7.5-8.5 \text {, tetapi bakteri masih dapat } \\
\text { beradaptasi pada } \mathrm{pH} \text { diluar kisaran }\end{array}$ \\
\hline Suhu & $20-35 \circ \mathrm{oC}$, proses nitrifikasi akan melambat drastis pada suhu dibawah $5 \circ \mathrm{C}$ \\
\hline Rentan terhadap toksin & $\begin{array}{l}\text { Bakteri nitrifikasi sensitif terhadap pencemar (ex: logam berat). Bakteri } \\
\text { nitrifikasi menjadi yang pertama mati jika ada pencemaran }\end{array}$ \\
\hline
\end{tabular}

Sumber : Riple (2003) 
Pengaruh Pemberian Probiotik Bacillus sp. terhadap Profil Kualitas Air,

Pertumbuhan dan Kelangsungan Hidup Benih Ikan Lele (Clarias gariepinus)

Tabel 3. Pengaplikasian Bakteri Probiotik

\begin{tabular}{|c|l|l|}
\hline Application & \multicolumn{1}{|c|}{ Identity of the probiotic } & \multicolumn{1}{|c|}{ Applied to aquatic species } \\
\hline \multirow{3}{*}{ Water Quality } & Bacillus sp. 48 & Penaeus monodon \\
& Bacillus NL 110, Vibrio sp. NE 17 & Macrobrachium rosenbergii \\
& Lactobacillus acidophilus & Clarias gariepinus \\
& B. coagulans SC8168 & Pennaeus vannamei \\
& Bacillus sp., Saccharomyces sp. & Penaeus monodon \\
\hline
\end{tabular}

Sumber: Cruz et al(2012)

tumbuh dan berkembang biak, sehingga menambah jumlah populasi bakteri dalam media uji. Kondisi ini dapat terjadi karena didukung oleh nilai beberapa parameter kualitas air media uji seperti DO,pH serta suhu yang sesuai untuk tumbuh dan berkembangbiaknya bakteri nitrifikasi ( Tabel 2).

Riple (2003) menyatakan bahwa :terdapat beberapa parameter kualitas air yang dibutuhkan bakteri nitrifikasi, seperti oksigen terlarut, $\mathrm{pH}$, suhu serta BOD (Tabel 3.)

Bakteri Bacillus Sp.banyak digunakan sebagai probiotik karena kemampuanya dalam menghasilkan senyawa antimikroba yang dapat menghambat perkembangan mikroorganisme lain yang merugikan. Semua jenis golongan bacillus akan menghasilkan senyawa antimikroba ini dalam kondisi tertentu apabila ada senyawa inducer yang mampu menginduksi biosintesis senyawa antimikroba ini dalam sel nya. Seperti halnya tiram dalam memproduksi mutiara harus diinduksi oleh benda asing yang masuk dalam cangkangnya. Begitu juga dengan biosintesis antimikroba ini akan terjadi apabila diinduksi oleh senyawa-senyawa tertentu.

Kandungan senyawa inducer ini terdapat dalam prebiotik yang mengatur alur metabolisme bakteri melaui modifikasi nutrisi yang komplek. Jadi agar probiotik berfungsi maksimal maka harus dilengkapi dengan prebiotik yang mengandung senyawa-senyawa inducer yang menginduksi metabolisme bakteri supaya menghasilkan metabolit-metabolit yang menguntungkan.

Selain senyawa inducer, keberhasilan probiotik juga tergantung dari $\mathrm{pH}$ optimum spesies bakteri yang terkandung dalam probiotik tersebut. Masing-masing spesies bakteri tersebut punya karakter spesifik dan dan punya daya kerja $\mathrm{pH}$ optimum. Berikut adalah daya kerja $\mathrm{pH}$

Tabel 4. Nilai Ph Optimum untuk Bacillus sp

\begin{tabular}{|l|l|}
\hline \multicolumn{1}{|c|}{ Bakteri } & pH Optimum \\
\hline Bacillus subtilis & $7.3-8.1$ \\
\hline Bacillus brevis & $6.5-7.5$ \\
\hline Bacillus megaterium & $7.0-7.5$ \\
\hline Bacillus polymixa & $6.0-7.2$ \\
\hline Bacillus amyloliquefaciens & $8.2-9.7$ \\
\hline Bacillus alvei & $6.5-7.5$ \\
\hline Bacillus coagulans & $7.5-9.0$ \\
\hline Bacillus licheniformis & $7.3-8.8$ \\
\hline Bacillus pumilus & $8.3-9.8$ \\
\hline
\end{tabular}




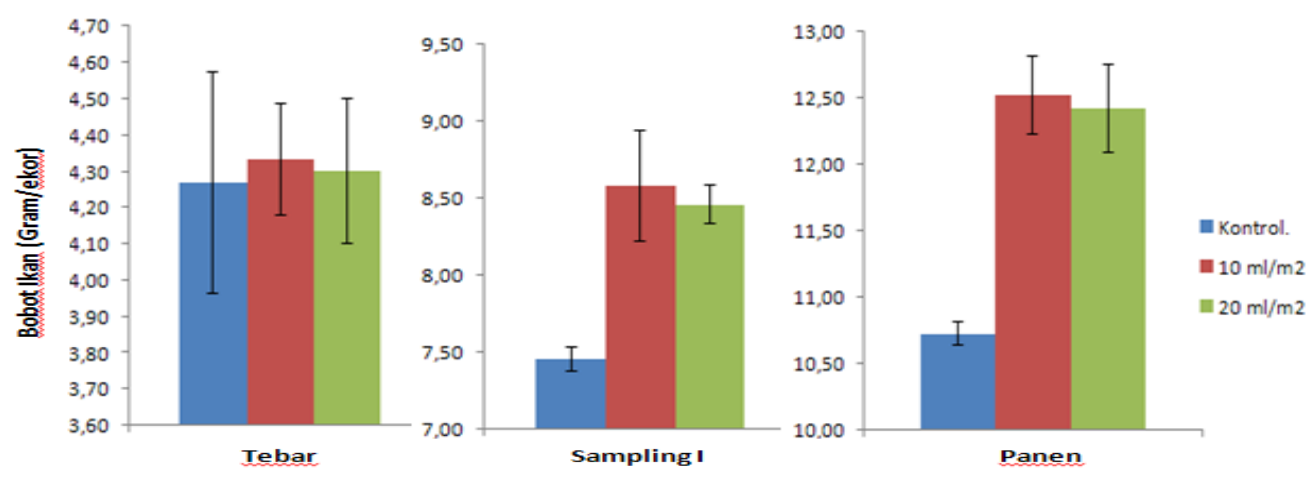

Gambar 1. Grafik Pertumbuhan (Berat) Ikan Uji

optimum dari masing-masing bakteri sbb:

Penambahan bakteri dari kelompok Nitrifikasi kedalam perlakuan I $\left(10 \mathrm{ml} / \mathrm{m}^{3}\right)$ dan II $\left(20 \mathrm{ml} / \mathrm{m}^{3}\right)$ bertujuan untuk mendukung proses nitritasi dan nitratasi di dalam masing-masing media pemeliharaan ikan uji. Reaksi dari kedua proses tersebut adalah sebagai berikut:

Nitritasi: oksidasi amonia menjadi nitrit oleh bakteri nitrit. Proses ini dilakukan oleh kelompok bakteri Nitrosomonas dan Nitrosococcus.

Nitratasi: oksidasi senyawa nitrit menjadi nitrat oleh bakteri nitrat. Proses ini dilakukan oleh kelompok bakteri Nitrobacter ${ }^{]}$

Dari hasil penelitian, diketahui bahwa bakteri yang digunakan diduga dapat bekerja sesuai dengan kedua rekasi diatas, terlihat dari adanya perbedaan dari nilai nitrit dan nitrat pada bak kontrol, perlakuan I dan II (Tabel 2.). Bakteri nitrifikasi merupakan bakteri aerobik, sehingga dalam prosesnya selalu membutuhkan oksigen. Hal ini dapat dilihat pada persamaan reaksi diatas, dimana bakteri nitrifikasi membutuhkan oksigen untuk dapat mengubah $\mathrm{NH}_{4}{ }^{+}$menjadi $\mathrm{NO}_{3}{ }^{-}$. Ripple (2003) menyatakan bakteri nitrifikasi membutuhkan $4.6 \mathrm{mg} / \mathrm{l}$ oksigen untuk dapat mengoksidasi $1 \mathrm{mg}$ amonia. Dan untuk dapat bekerja secara optimal, bakteri nitrifikasi membutuhkan oksigen terlarut (dissolved oxygen) minimal $2 \mathrm{mg} / 1$.
Berfungsinya bakteri nitrifikasi jenis Bacillus sp yang digunakan sebagai probiotik dalam penelitian ini, sesuai dengan hasil dari penelitian Cruz et al (2012), menyatakan bahwa Bacillus sp merupakan bakteri probiotik yang dapat diaplikasikan untuk memperbaiki kualitas air (Tabel 5.)

Subuntith et al (2012), menyatakan bahwa penggunaan probiotik Bacillus sp meningkatkan pertumbuhan Litopenaeus vannamei, dan menurunkan nilai nitrit di media uji. Hal ini sejalan dengan hasil penelitian yang menunjukan adanya penurunan nilai nitrit pada media perlakuan I dan II diabndingkan dengan kontrol, dimana masing-masing nilai nitrit berturut-turut adalah : 0,02 ppm; 0,1 dan 0,63. Joseph et al (2014) menyatakan bahwa penggunaan probiotik menurunkan nilai amoniak dan nitrit pada kolam pemeliharaan ikan uji.

Nitrit merupakan bentuk peralihan antara ammonia dan nitrat (nitrifikasi), reaksinya berlangsung dengan cepat dan dipengaruhi oleh jumlah konsentrasi ammonia yang dioksidasi sehingga memiliki orde reaksi 2. Nitrit berbahaya karena nitrit bergabung dengan ion hidrogen membentuk asam nitrous $\left(\mathrm{HNO}_{2}-\mathrm{N}\right)$ yang berupa asam kuat dan karena tidak bermuatan listrik sehingga dengan bebas dapat berdifusi melintasi membran insang atau melalui transport aktif. Mekanisme efek toksik nitrit adalah ketika asam 
Pengaruh Pemberian Probiotik Bacillus sp. terhadap Profil Kualitas Air,

Pertumbuhan dan Kelangsungan Hidup Benih Ikan Lele (Clarias gariepinus)

nitrous berdifusi ke dalam darah melalui insang lalu bereaksi dengan besi II $\left(\mathrm{Fe}^{2+}\right)$ menghasilkan besi III $\left(\mathrm{Fe}^{3+}\right)$. Hal ini akan mengurangi kemampuan sel darah merah untuk mengikat oksigen, yang mengakibatkan penyakit darah coklat (methemoglobin) yang dapat mematikan ikan karena kekurangan oksigen (hypoxia) (Boyd, 1990).

Bakteri Bacillus sp. banyak digunakan sebagai probiotik karena kemampuannya dalam menghasilkan senyawa antimikroba yang dapat menghambat perkembangan mikroorganisme lain yang merugikan. Semua jenis golongan Bacillus akan menghasilkan senyawa antimikroba ini dalam kondisi tertentu apabila ada senyawa inducer yang mampu menginduksi biosintesis senyawa antimikroba ini dalam sel nya. Seperti halnya tiram dalam memproduksi mutiara harus diinduksi oleh benda asing yang masuk dalam cangkangnya. Begitu juga dengan biosintesis antimikroba ini akan terjadi apabila diinduksi oleh senyawa-senyawa tertentu.

Linggarjati et al (2013) menyatakan bahwa pemberian kandidat probiotik Bacillus sp. dengan kepadatan $10^{6} \mathrm{cfu} / \mathrm{ml}$ dapat menurunkan kandungan amoniak $\left(\mathrm{NH}_{3}\right), \operatorname{nitrit}\left(\mathrm{NO}_{2}\right)$ dan jumlah total bakteri. Sedangkan pemberian kandidat probiotik dengan kepadatan $10^{5} \mathrm{cfu} / \mathrm{ml}$ dapat menurunkan jumlah total bakteri media pemeliharaan rajungan, akan tetapi tidak menurunkan kandungan amoniak $\left(\mathrm{NH}^{3}\right)$ dan nitrit $\left(\mathrm{NO}_{2}\right)$.

Kandungan senyawa inducer ini terdapat dalam prebiotik yang mengatur alur metabolisme bakteri melaui modifikasi nutrisi yang komplek. Jadi agar probiotik berfungsi maksimal maka harus dilengkapi dengan prebiotik yang mengandung senyawa-senyawa inducer yang menginduksi metabolisme bakteri supaya menghasilkan metabolit-metabolit yang menguntungkan. Selain senyawa inducer, keberhasilan probiotik juga tergantung dari $\mathrm{pH}$ optimum spesies bakteri yang terkandung dalam probiotik tersebut. Masing-masing spesies bakteri tersebut punya karakter spesifik dan dan punya daya kerja $\mathrm{pH}$ optimum.

Beberapa produk sediaan bakteri mengandung lebih dari tiga macam bakteri dengan maksud untuk mengantisipasi fluktuasi parameter kimia dilingkungan tersebut. Sehingga semakin beragam kandungan bakteri dalam suatu produk maka semakin besar kemungkinan beberapa spesies dapat bekerja optimum.

Nilai DO, suhu dan $\mathrm{pH}$ selama masa pemeliharaan cenderung relatif sama disemua perlakuan dan kontrol. Nilai DO dari media kontrol Perlakuan I dan Perlakuan II secara berturut-turut adalah 6,80 ppm; 6,89 ppm dan 6,92 ppm. Nilai suhu mulai dari kontrol sampai perlakuan I dan II adalah $28^{\circ} \mathrm{C}$. Nilai pH untuk kontrol perlakuan I dan II adalah 6,6; 6,4 dan 6,6. Berdasarkan Cruz et al (2012), DO, suhu dan pH pada penelitian ini berada dalam rentang nilai yang dapat mendukung pertumbuhan dan perkembangbiakan bakteri probiotik Bacillus sp. DM de Souza et al (2012) dalam Zoekaeifar et al (2014) menyatakan bahwa penggunaan probiotik dapat membantu mengontrol kualitas air dalam media pemeliharaan Farfantepenaeus brasiliensis.

Pertumbuhan, Kelangsungan Hidup, dan Feed Conversi Ratio (FCR)

Berdasarkan uji statistik pada selang kepercayaan 95\%, terdapat perbedaan nilai pertumbuhan (berat) yang nyata antar kontrol dan perlakuan, sedangkan antara perlakuan I dan II tidak berbeda nyata (Gambar 1 dan Tabel 6 ). 


\begin{tabular}{|c|c|c|c|c|}
\hline Probiotic strain & Source & Used on & Method of application & Reference \\
\hline $\begin{array}{l}\text { Streptococcus lactis and } \\
\text { Lactobacillus bulgaricus }\end{array}$ & $?$ & $\begin{array}{l}\text { Turbot larvae } \\
\text { (Scophthalmus maximus) }\end{array}$ & $\begin{array}{l}\text { Enrichment of } \\
\text { live food }\end{array}$ & $\begin{array}{l}\text { García de la Banda } \\
\text { et al. (1992) }\end{array}$ \\
\hline $\begin{array}{l}\text { Lactobacillus sp. and } \\
\text { Carnobacterium sp. }\end{array}$ & $\begin{array}{l}\text { Rotifers (Brachionus } \\
\text { plicatilis) }\end{array}$ & Turbot larvae & $\begin{array}{l}\text { Enrichment } \\
\text { of rotifers }\end{array}$ & Gatesoupe (1994) \\
\hline Vibrio alginolyticus & $\begin{array}{l}\text { Commercial shrimp } \\
\text { hatchery }\end{array}$ & $\begin{array}{l}\text { Atlantic salmon } \\
\text { (Salmo salar L.) }\end{array}$ & $\begin{array}{l}\text { Bathing in bacterial } \\
\text { suspension }\end{array}$ & Austin et al. (1995) \\
\hline Carnobacterium divergens & $\begin{array}{l}\text { Intestines of } \\
\text { Atlantic salmon }\end{array}$ & Atlantic cod fry & Addition to dict & $\begin{array}{l}\text { Gildberg and Mikkelsen } \\
\text { (1998) }\end{array}$ \\
\hline $\begin{array}{l}\text { Bacillus megaterium, } \\
\text { B. subtilis, B. polymyxa, } \\
\text { B. licheniformis }\end{array}$ & $\begin{array}{l}\text { Commercial product } \\
\text { (Biostart) }\end{array}$ & Channel catfish & $\begin{array}{l}\text { Addition to } \\
\text { pond water }\end{array}$ & Queiroz and Boyd (1998) \\
\hline Vibrio pelagius & Turbot larvac & Turbot & $\begin{array}{l}\text { Addition to } \\
\text { culture water }\end{array}$ & Ring $\emptyset$ and Vadstein (1998) \\
\hline G-probiotic & Commercial product & Oreochromis niloticus & Addition to diet & Naik et al. (1999) \\
\hline Pseudomonas fluorescens & $\begin{array}{l}\text { Iced freshwater fish } \\
\text { (Lates niloticus) }\end{array}$ & $\begin{array}{l}\text { Rainbow trout } \\
\text { (Oncorhynchus mykiss) }\end{array}$ & $\begin{array}{l}\text { Addition to } \\
\text { culture water }\end{array}$ & Gram et al. (1999) \\
\hline Carnobacterium sp. & $\begin{array}{l}\text { Intestines of } \\
\text { Atlantic salmon }\end{array}$ & Atlantic salmon & Addition to diet & Robertson et al. (2000) \\
\hline $\begin{array}{l}\text { Lactobacillus rhamnosus } \\
\text { ATCC } 53103\end{array}$ & Culture collection & Rainbow trout & Addition to diet & Nikoskelainen et al. (2001) \\
\hline $\begin{array}{l}\text { Aeromonas hydrophila, } \\
\text { Vibrio fluvialis, } \\
\text { Carnobacterium sp., } \\
\text { Micrococcus luteus }\end{array}$ & $\begin{array}{l}\text { Digestive tract of } \\
\text { rainbow trout }\end{array}$ & Rainbow trout & Addition to diet & Irianto and Austin (2002) \\
\hline Enterococcus faecium SF68 & $\begin{array}{l}\text { Commercial product } \\
\text { (Cernivet) }\end{array}$ & Anguilla anguilla & Addition to diet & Chang and Liu (2002) \\
\hline L. rhamnosus JCM 1136 & Culture collection & Rainbow trout & Addition to diet & Panigrahi et al. (2004) \\
\hline Roseobacter sp. strain 27-4 & $\begin{array}{l}\text { Turbot larvae, Tetraselmis } \\
\text { copepod-fed larvae }\end{array}$ & Turbot larvae & $\begin{array}{l}\text { Addition to } \\
\text { culture water }\end{array}$ & Hjelm et al. (2004) \\
\hline Bacillus circulans & Intestines of Labeo rohita & L. rohita & Addition to diet & Ghosh et al. (2004) \\
\hline
\end{tabular}
dilihat bahwa perlakuan I (pemberian probiotik $10 \mathrm{ml} / \mathrm{m}^{3}$ ) memiliki nilai pertumbuhan harian tertinggi sebesar 12,52 $\pm 0,29 \mathrm{~b}$, disusul perlakuan II (pemberian probiotik $20 \mathrm{ml} / \mathrm{m}^{3}$ ) sebesar $12,42 \pm 0,33 \mathrm{~b}$, serta kontrol sebesar 10,72 \pm 0,09a. Rane dan Aishwarya (2015), Raja et al (2015) serta S Ghouse (2015) menyatakan bahwa penggunaan probiotik akan meningkatkan sistem imun dan hal ini berkorelasi positif dengan tingkat pertumbuhan ikan uji. Michael et al (2014) menyatakan bahwa probiotik salahsatu promotor bagi pertumbuhan ikan.

Sistem imun ikan dapat ditingkatkan dengan berbagai cara, diantaranya melalui mekanisma senyawa penghambat pertumbuhan patogen yang dihasilkan oleh bakteri mengemukakan bahwa bakteri antagonis dalam perannya sebagai agen pengendalian hayati melalui mekanisme menghasilkan senyawa penghambat pertumbuhan patogen, kompetisi pemanfaatan senyawa tertentu atau kompetisi tempat menempel, mempertinggi respon imun inang, meningkatkan kualitas air dan adanya interaksi dengan fitoplankton. Bakteri antagonis yang digunakan sebagai agen pengendalian hayati dimasukkan dalam istilah probiotik. Probiotik merupakan mikrobia yang diberikan dengan berbagai cara sehingga masuk dalam saluran pencernaan dengantujuan mempertinggi derajat kesehatan inang atau kualitas lingkungan. Bakteri Bacillus adalah bakteri gram positif Tabel 6. Nilai Pertumbuhan (Berat) Ikan Uji

\begin{tabular}{|c|c|c|c|}
\hline Perlakuan & Tebar & Sampling I & Panen \\
\hline Kontrol. & $4,27 \pm 0,31 \mathrm{a}$ & $7,45 \pm 0,08 \mathrm{a}$ & $10,72 \pm 0,09 \mathrm{a}$ \\
\hline $10 \mathrm{ml} / \mathrm{m}^{2}$ & $4,33 \pm 0,15 \mathrm{a}$ & $8,58 \pm 0,36 \mathrm{~b}$ & $12,52 \pm 0,29 \mathrm{~b}$ \\
\hline $20 \mathrm{ml} / \mathrm{m}^{2}$ & $4,30 \pm 0,20 \mathrm{a}$ & $8,46 \pm 0,12 \mathrm{~b}$ & $12,42 \pm 0,33 \mathrm{~b}$ \\
\hline
\end{tabular}


Pengaruh Pemberian Probiotik Bacillus sp. terhadap Profil Kualitas Air,

Pertumbuhan dan Kelangsungan Hidup Benih Ikan Lele (Clarias gariepinus)

sehingga tercat berwarna ungu. Seleksi kandidat probiotik dilakukan melalui uji antagonis terhadap bakteri $V$. Harveyii. Uji antagonis dilakukan dengan metode difusi agar menggunakan paper disc. Kandidat probiotik ditunjukan oleh terbentuknya zona hambat di sekitar (Yudiati, 2005 dalam Linggarjati 2013).

Menurut Balcazar et al (2006), pengendalian hayati adalah penggunaan musuh alamiah untuk mengurangi kerusakan yang ditimbulkan oleh organisme yang berbahaya atau pengaturan populasi penyakit oleh musuh alamiahnya, yang diantaranya adalah bakteri robiotik.. Beberapa jenis probiotik dalam akuakultur adalah sebagai berikut :

Nilai pertumbuhan untuk panjang ikan uji, dapat dilihat pada Gambar 2 dan Tabel 7. Berikut ini.

Perhitungan pertumbuhan harian berdasarkan panjang dimaksudkan untuk melihat apakah pola pertumbuhan yang terjadi pada ikan uji hanya sampai kepada bobot ataukah sudah ke arah pertumbuhan panjang Berdasarkan uji statistik $(\mathrm{p}<0.05)$, tidak terdapat beda nyata antara perlakuan dengan kontrol. Laju pertumbuhan ikan uji mulai dari perlakuan I, II serta kontrol adalah $12,5 \pm 0,3 \mathrm{a} ; 12,5 \pm 0,4 \mathrm{a}$ dan 12,2 \pm 0,5a.Menurut Effendie, (1997) faktorfaktor yang mempengaruhi pertumbuhan ada 2, yaitu faktor dalam (internal) dan faktor luar (eksternal). Faktor dalam berupa keturunan, dan jenis kelamin,. Sedangkan faktor luar berupa ketersediaan makanan, kualitas air, dan ruang gerak.

Tingkat kelangsungan hidup ikan uji selama masa pemeliharaan berkisar antara 79,8 87,5\% (Gambar 3, dan Tabel 8).

Berdasarkan Tabel 8, terlihat bahwa pada selang kepercayaan 95\%, uji statistik yang dilakuan tidak memberikan hasil yang berbeda nyata untuk kontrol dan semua perlakuan. Hal ini menandakan bahwa pemberian bakteri probiotik Bacillus sp. tidak memberikan pengaruh yang nyata terhadap tingkat kelangsungan hidup ikan uji selama masa pemeliharaan.

Nilai FCR kontrol, perlakuan I dan II, berturut-turut adalah $0,71: 0,63 ; 0,60$. Dari hasil perhitungan diketahui bahwa nilai FCR tidak berbeda nyata untuk semua perlakuan. Nilai kecernaan menggambarkan banyaknya nutrisi yang dapat diserap ikan dari pakan (NRC, 1993), dan berkorelasi dengan tingkat efisiensi terhadap pakan dan pertumbuhan. Diduga nilai FCR baik pada kontrol maupun perlakuan tidak berbeda nyata karena bakteri probiotik yang diaplikasikan diarahkan pada perbaikan bebrapa parameter kualitas air, dan tidak berpengaruh terhadap komposisi enzim dalam saluran pencernaan, yang merupakan salah satu faaktor penentu dalam pennyerapan nutrisi pakan. Nilai FCR diduga akan berubah pada saat probiotik yang digunakan, adalah probiotik yang bekerja dalam sistem pencernaan.

Kondisi diatas sesuai dengan hasil penelitian Eliyani (2013) yang menyatakan

Tabel 7. Nilai Pertumbuhan (Panjang) ikan Uji

\begin{tabular}{|c|c|c|c|}
\hline Perlakuan & Tebar & Sampling I & Panen \\
\hline Kontrol. & $7,4 \pm 0,2 \mathrm{a}$ & $8,1 \pm 0,3 \mathrm{a}$ & $12,2 \pm 0,5 \mathrm{a}$ \\
\hline $10 \mathrm{ml} / \mathrm{m}^{2}$ & $7,4 \pm 0,2 \mathrm{a}$ & $8,6 \pm 0,4 \mathrm{ab}$ & $12,5 \pm 0,3 \mathrm{a}$ \\
\hline $20 \mathrm{ml} / \mathrm{m}^{2}$ & $7,4 \pm 0,2 \mathrm{a}$ & $8,59 \pm 0,1 \mathrm{~b}$ & $12,5 \pm 0,4 \mathrm{a}$ \\
\hline
\end{tabular}




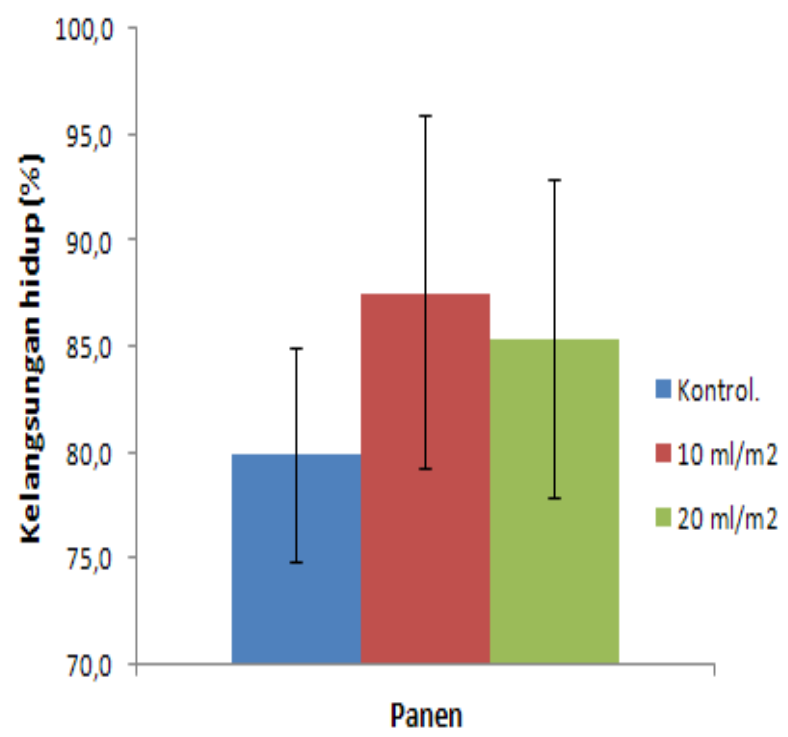

Gambar 3. Grafik Kelangsungan Hidup Ikan Uji

bahwa penggunaan Probiotik Lactobacillus brevis dengan simbiotik FOS GOS menurunkan nilai Feed Conversi Ratio/ FCR ikan uji. Probiotik, prebiotik dan sinbiotik mampu menurunkan nilai FCR dibandingkan perlakuan $\mathrm{K}(+)$ dan $\mathrm{K}(-)$. Hal ini diduga terjadi karena pada perlakuan pro, pre dan sin sinbiotik, populasi bakteri yang menguntungkan di dalam usus ikan uji mengalami peningkatan baik karena adanya asupan L.brevis, ataupun asupan FOS serta GOS yang dimanfaatkan oleh bakteri indigenous, sehingga enzim (protease, amilase, lipase) yang dihasilkan oleh bakteri tersebut akan bertambah dan akhirnya mampu mendukung sistem pencernaan (Narges et al., 2012). Sistem pencernaan ikan juga terkaitan erat dengan kondisi kualitas air media pemeliharaan. Semakin baik kualitas air media, akan mampu meningkatkan nafsu makan ikan; yang pada gilirannya akan mengoptimalkan metabolisme.

\section{Kesimpulan dan Saran}

Kesimpulan

Penambahan bakteri probiotik dari jenis Bacillus sp mempengaruhi profil kualitas air untuk parameter nitrit dengan nilai kontrol, perlakuan 1 dan 2 berturut-turut sebesar 0,63 ppm; 0,02 ppm dan 0,1 ppm. Nilai nitrat mulai dari kontrol, perlakuan 1 dan 2 berturut-turut adalah sebesar 13,1 ppm; 0,22 ppm dan 0,22 ppm. Parameter. kualitas air yang terdiri dari DO, suhu serta $\mathrm{pH}$ pada semua perlakuan selama masa pemeliharaan masih berada dalam kisaran toleransi ikan uji. Perlakuan penambahan bakteri probiotik memberikan hasil yang terbaik untuk pertumbuhan berat pada dosis $10 \mathrm{ml} / \mathrm{m}^{3}$ dengan nilai 12,52 $\pm 0,29$ dibanding dengan kontrol dan perlakuan yang lain. Tingkat kelangsungan hidup, tidak menunjukkan beda nyata di semua perlakuan dan kontrol, dengan rentang nilai antara $79,8-87,5 \%$.

Tabel 8. Data Sintasan (kelangsungan hidup) ikan uji (\%)

\begin{tabular}{|c|c|c|}
\hline Perlakuan & Tebar & Panen \\
\hline Kontrol. & $100 \pm 0,0$ & $79,8 \pm 5,0 \mathrm{a}$ \\
\hline $10 \mathrm{ml} / \mathrm{m}^{2}$ & $100 \pm 0,0$ & $87,5 \pm 8,4 \mathrm{a}$ \\
\hline $20 \mathrm{ml} / \mathrm{m}^{2}$ & $100 \pm 0,0$ & $85,3 \pm 75 \mathrm{a}$ \\
\hline
\end{tabular}




\section{Saran}

Hasil penelitian ini dapat diaplikasikan oleh pembudidaya maupun masayarakat luas, pada media budidaya yang lebih luas, seperti kolam tanah atau kolam terpal. Perlu dilakukan penyusunan analisa kelayakanusaha untuk kegiatan ini.

\section{Daftar Pustaka}

Abareethan, M., A. Amsath. 2015. Characterization and Evaluation of Probiotic Fish Feed. International Journal of Pure and Applied Zoology Volume 3, Issue 2, pp: 148-153.

Balca'zar, Jose' Luis. Ignacio de Blas. Imanol Ruiz-Zarzuela. David Cunningham. Daniel Vendrell. Jose' Luis Mu'zquiz. Review The role of probiotics in aquaculture. 2006. Veterinary Microbiology 114( 173-186 ).

Boyd AW. 1990. Water quality in pond for aquaculture. Auburn University. Birmingham Publishing Co. Alabama.

Chamberlain G, Avnimelech Y, McIntosh RP, Velasco M. 2001. Advantages of aerated microbial reuse systems with balanced $\mathrm{C} / \mathrm{N}$ : Nutrient tranformation and water quality benefits. Global Aquaculture Alliance : April 2001.

Cruz,PatriciaMart'inez., Ana L. Ib'ãnez., Oscar A. Monroy Hermosillo., Hugo C. Ram'irez Saad. Use of Probiotics in Aquaculture. $2012 . \quad$ ISRN Microbiology . Volume 2012, Article ID 916845,13 pages

Effendie MI. 1979. Metode biologi perikanan. Yayasan Dewi Sri. Bogor.

H, Jamali., Tafi, A.A., Jafaryan, H. Patimar, R. 2014. Effect of Enriched Artemia parthenogenetica (Bacillus spp.) on Growth, Survival, Fecal Production and Nitrogenous Excretion in Rainbow Trout (Oncorhynchus mykiss) Larvae. J.Fisheries Livest Prod Vol 2, Issue 1.

Huisman EA. 1987. Principles of fish production. Departemen of fish culture and fisheriesWageningen Agricultural University. Wageningen/Netherland.

Joseph, Valsamma., M. Haseeb., S. Ranjit., A. Anas., I.S.Bright Singh. 2014. Shrimpi
Production under Zero Water Exchange Mode Coupled with Bioremediation and Aplication of Probiotics. Journal of Fisheries International 9 (1) , 5-14.

Lazado, C.C., Caioang, C.M.A. 2014. Atlantic Cod in The Dynamic Probiotics Research in Aquaculture., p424-425.

Linggarjati, Kharisma Firdaus. Ali Djunaedi. Subagiyo. 2013. Uji Penggunaan Bacillus sp. sebagai Kandidat Probiotik Untuk Pemeliharaan Rajungan (Portunus sp.). Journal Of Marine Research.Volume 2, Nomor 1 (1-6).

Metcalf dan Eddy. 1991. Wastewater engineering : treatment, disposal, and reuse. McGraw-Hill, New York.

Michael, Ekundayo Taiye Michael., Sogbesan Olukayode Amos., Lauratu Tahir Hussaini. 2014. A Review on Probiotics Application in Aquaculture. Fish Aquac J , 5:4.

Montoya R dan Velasco M. 2000. Role of bacteria on nutritional and management strategies in aquaculture systems. Global Aquaculture Alliance

National Research Council (NRC). 1993. Nutrient requirements of fish. Sub committee on fish nutrition, National Research Council. National Academic Press (USA). 114p.

Rane, Madhavi. 2015. Effects of Probiotic on the Growth and Survival of Zebra fish (Danio rerio). International Journal of Science and Research (IJSR) Volume 4 Issue 3, March.

S Ghouse, Mohammed. 2014. Use of Probiotics as Biological Control Agents in Aquaculture for Sustainable Development. International Journal of Food, Agriculture and Veterinary Sciences Vol.5 (1) January-April.

Subuntith Nimrat.,Sunisa Suksawat,, Traimat Boonthai'Verapong Vuthiphandchai. Potential Bacillus probiotics enhance bacterial numbers, water quality and growth during early development of white shrimp (Litopenaeus vannamei). 2012. Veterinary MicrobiologyVolume 159, Issues 3-4, 12 October 2012, Pages $443-450$ 
Zokaeifar, Hadi., Nahid Babaei., Che Ros Saad., Mohd Sallesh Kamarudin., Kamaruzaman Sijam., Jose Luis Balcazar. 2014. Adiministration of Bacillus subtilis in The Rearing Water Enhances The Water Quality, Growth, Performance, Immune Response, and Resistance Against Vibrio harveyi Infection in Juvenile White Shrimp, Litopenaeus vannamei. Fish and Shellfish Immunology J, 36, 68-74. 